\title{
AZ MTA RÓMAI MAGYAR TÖRTÉNETI INTÉZETE ÉS UTÓDA, A KILENCVEN ÉVVEL EZELŐTT ALAPÍTOTT RÓMAI MAGYAR AKADÉMIA
}

\section{THE 90 YEARS OF THE HUNGARIAN ACADEMY IN ROME AND ITS PREDECESSOR, THE HUNGARIAN HISTORICAL INSTITUTE IN ROME}

\author{
Sárközy Péter \\ full-professzor, La Sapienza Egyetem Magyar Tanszék, Róma; \\ tag, Olasz Nemzeti Árkádia Irodalmi Akadémia; nyugdijas tudományos tanácsadó, MTA Irodalomtudományi Intézet \\ peter.sarkozy@uniroma1.it
}

\section{ÖSSZEFOGLALÁS}

Kilencven évvel ezelőtt, 1928. április 26-án született meg a Római Magyar Akadémia megalapításáról szóló okirat, és az év végén költöztek be az első tudományos ösztöndíjasok a Borromini által épített Palazzo Falconieri palotába, valamint a festők és szobrászok a számukra a palota mellett létrehozott kétemeletes Művészházba (Palazzina).

Ugyanakkor a római magyar "Akadémia" története ennél sokkal régebbi, pontosabban 123 évre néz vissza, hiszen az intézmény elődjét, a Magyar Tudományos Akadémia főtitkára, majd elnökhelyettese, Fraknói Vilmos címzetes püspök alapította 1895-ben. Az új egyetemi negyedben az általa vásárolt és építtetett (Fraknói) villában létesült a Római Magyar Történeti Intézet, amikor azt követően, hogy XIII. Leo pápa a történeti kutatások elősegítésére megnyitotta a Vatikáni Levéltárat, Rómában sorra létesültek a különböző nemzetek tudományos intézetei.

A római Magyar Történeti Intézetnek köszönhető a Monumenta Vaticana historiam regni Hungariae illustrantia kiadványsorozat köteteinek és más fontos kutatások eredményeinek kiadása. Fraknói Vilmos 1913-ban a Római Történeti Intézetet teljes felszerelésével, a tudományos könyvtárral és az ott létesített múvészházzal együtt a Magyar Tudományos Akadémia kezelésére bízta, a magyar államnak ajándékozta, és nagyobb pénzalapítványt helyezett el a kutatók ösztöndíjának biztosítására.

1928-ban jött létre a Római Magyar Akadémia, melynek négy nagy szekciója volt: tudományos szekció hét kutató számára; mellette a gimnáziumi tanárok tudományos kutatását lehetővé tevő Collegium Hungaricum, a festők és szobrászok részére létrehozott művészház és a palota II. emeletén a máig önállóan létező egyházi szekció, amelyet 1940-ben XII. Pius pápa beiktatott a római pápai intézetek sorába.

1949-1960 között a Falconieri Palota a Magyar Nagykövetség személyzetének lett lakóhelye, és csak 1965 után kezdődött meg újra a Római Akadémián a tudományos és múvészi ösztöndíjasok fogadása.

A tanulmány, bemutatva az intézmény utolsó harminc évének történetét, rámutat arra, hogy szükséges lenne, ha a tudományos kutatások felügyelete és az ösztöndíjas kutatók kiválasztása ismét a Magyar Tudományos Akadémia erre alapítandó kuratóriuma alá kerüljön, ugyanakkor a Rómában hosszabb ideig alkotni és műveiket kiállítani kívánó művészek kiválasztása a Magyar 
Művészeti Akadémia feladata lehetne, míg a Balassi Intézet továbbra is ellátná a Római Magyar Akadémián és más olasz városokban a kulturális rendezvények szervezését. Ezzel egy időben vissza kellene állítani a főépületben a tudományos kutatók lakásait, és a művészházban a műtermekkel ellátott ösztöndíjas lakásokat.

\section{ABSTRACT}

Ninety years ago, on $26^{\text {th }}$ April 1928 the founding document of the Hungarian Academy in Rome was issued. The first scholarship holders moved in at the end of the same year: researchers into the Palazzo Falconieri built by Borromini, painters and sculptors into the two-storeyed Artists' House erected for them next to the palace.

However, the Hungarian Academy in Rome has a much longer history, since its predecessor has been founded 123 years ago in 1895 by Titular Bishop Vilmos Fraknói, First Secretary and later Vice President of the Hungarian Academy of Sciences. The "Hungarian Historical Institute" in Rome began its activity in the Villa Fraknói built on the Monsignor's expense on a plot bought by him in the new university district at the time when, following the opening of the Vatican Archives by Pope Leo XIII in order to facilitate historical research, several nations founded scholarly institutes in Rome.

The Hungarian Historical Institute was responsible for the publication of the series Monumenta Vaticana historiam regni Hungariae illustrantia as well as of other important research results. In 1913 Vilmos Fraknói placed the Institute under the care of the Hungarian Academy of Sciences donating it to the Hungarian state with its entire equipment and library as well as with the Artists' House founded there. He also created a significant scholarships fund for researchers.

Thus the Hungarian Academy in Rome was established in 1928 in Falconieri Palace. The new institution had four sections: a scholarly section for 7 researchers; a Collegium Hungaricum offering research possibilities for secondary school teachers; an Artists' House created for painters and sculptors; and an ecclesiastical section that has been functioning independently ever since on the second floor of the palace. This latter section was included among the papal institutes of Rome by Pope Pius XII. Between 1948 and 1960 the Palazzo Falconieri served as a dwelling place for the personnel of the Hungarian Embassy. The Hungarian Academy in Rome began to receive researchers and artists with scholarships only after 1965.

The paper presenting the history of the institution in the last thirty years points out that the research work and the awarding of scholarships ought to be overseen by an advisory board of the Hungarian Academy of Sciences organized for this particular purpose. At the same time selecting of artists who wish to work for a protracted period in Rome and exhibit their creations there could be the task of the Hungarian Artistic Academy, while the Balassi Institute could continue to organize cultural events at the Hungarian Academy in Rome as well as in other Italian towns. The flats and studios formerly used on a scholarship basis by researchers and artists in the main building, respectively in the Artists' House should be restored as well.

Kulcsszavak: Történeti Intézet (Róma), Római Magyar Akadémia, alapítás, történet, 1895-2017

Keywords: Hungarian Historical Institute in Rome, Hungarian Academy in Rome, foundation, history, 1895-2017 
Már a 2017/18-as „akadémiai év” elején elkezdődtek Rómában a kilencven évvel ezelőtt alapított Római Magyar Akadémia ünnepi rendezvényei, bár az alapító okiratot 1928. április 26-án írták alá a Magyar Tudományos Akadémia és a Vallás és Közoktatási Minisztérium vezetői, és csak az év végén költöztek be az első ösztöndíjasok az épületbe A megnyitó ünnepséget 1929 őszén tartották a Via Giulia elején lévő barokk palotában, a Francesco Borromini által épített Palazzo Falconieriben, amely mellett a régi istállóból és személyzeti lakásokból az új intézmény akadémiai kurátora, Gerevich Tibor professzor külön mütermes lakásokból álló Mủvészházat alakított ki festők és szobrászok számára. Ugyanakkor a római magyar „Akadémia” története ennél sokkal régebbi, pontosabban 123 évre néz vissza, hiszen az intézmény elődjét már 1895-ben létrehozta a Magyar Tudományos Akadémia főtitkára, majd elnökhelyettese, Fraknói Vilmos címzetes püspök. Az új egyetemi negyedben, a Porta Pia közelében saját vagyonából vásárolt telken építtetett villájában létesült a Római Magyar Történeti Intézet. A magyar történészek és régészek számára létrehozott, tudományos könyvtárral ellátott intézmény az első külföldi tudományos intézetek sorába tartozik, melyek azt követően létesültek Rómában, hogy 1881-ben XIII. Leo pápa megnyitotta a Vatikáni Titkos Levéltárat a tudományos kutatók előtt (Vári, 1916).

A római Magyar Történeti Intézetnek köszönhető az egyik legfontosabb történeti forráskiadás, a Monumenta Vaticana historiam regni Hungariae illustrantia kiadványsorozat köteteinek létrejötte és más fontos alapkutatások eredményeinek kiadása. Fraknói Vilmos 1913-ban a Római Történeti Intézetet teljes felszerelésével, a tudományos könyvtárral és a villa mellett 1902-ben épített művészházzal együtt a magyar államnak ajándékozta és nagyobb pénzalapítványt létesített a kutatók ösztöndíjának biztosítására, azzal a feltétellel, hogy az alapítványt kizárólag tudományos (föleg történeti, archeológiai, régészeti, müvészettörténeti) kutatásokra használhatják, épp ezért az intézmény tudományos felügyeletét és irányítását az adománylevelében a Magyar Tudományos Akadémiára bízta. ${ }^{1}$

Az intézetet az első világháború alatt az olasz állam zárolta, és csak 1924-ben költözhettek be ismét a kutatók és a müvészek az épületekbe. Mivel a Fraknói-villában csak az intézet igazgatójának és négy kutatónak, a müvészházban pedig csak három müvésznek jutott hely, 1927-ben Gerevich Tibor professzor, a Történeti Intézet igazgatója javaslatára Klebelsberg Kunó vallás- és közoktatásügyi miniszter a római egyetemen a honoris causa diploma átvételekor bejelentette a magyar kormány szándékát, hogy a római Történeti Intézetet a bécsi és berlini Collegium Hungaricumok mintájára kibővíti (Fráter, 1974, 251-262.; Pásztor, 1993, 9-27.).

Így jött létre 1928-ban a Római Magyar Akadémia, az időközben megvásárolt Falconieri palotában, melynek négy nagy szekciója volt: a Fraknói Vilmos által ala-

${ }^{1}$ 130.992/1913. május 8. (Vö.: Ujváry, 1998, 20-24.) 
pított tudományos szekció (hét kutató számára); mellette a gimnáziumi és egyetemi magántanárok tudományos kutatását lehetővé tevő Collegium Hungaricum (tizenkét, egy szemeszteren keresztül Rómában kutató ösztöndíjas tanár, zenész, énekes és író számára); a festők és szobrászok részére létrehozott Müvészház és a palota II. emeletén a máig önállóan létező egyházi szekció, amelyet 1940-ben XII. Pius pápa beiktatott a római pápai intézetek sorába. A Fraknói Vilmos alapította történeti intézet 5000 kötetes tudományos könyvtárával együtt 1929-ben költözött át az addig az ösztöndíjasok fogadására átalakított Palazzo Falconieribe. Az önálló Pápai Intézeten kívül (Tóth, 2017) az új Római Akadémia szekcióinak szakmai irányítására és felügyeletére a Magyar Tudományos Akadémia és a Vallás- és Közoktatásügyi Minisztérium által megbízott, szakemberekből álló, Gerevich Tibor művészettörténész professzor által vezetett tudományos kuratóriumot hozott létre. Ennek tagjai neves tudósok voltak, mint Eckhardt Sándor, Keresztury Dezső, Magyary Zoltán, Szekfü Gyula vagy Szent-Györgyi Albert. Az új Magyar Intézet római igazgatói egyetemi tanárok voltak, akik egyben a Római Tudományegyetem, a La Sapienza 1929/30-as tanévben alapított magyar tanszékének professzori tisztségét is betöltötték (Miskolczy Gyula, 1930-1935; Koltay-Kastner Jenő, 1935-1940; Genthon István, 1940-1943; majd a háború után Kardos Tibor, 1947-1949). A római igazgatók fő feladata az épület fenntartásának és az intézet tudományos müködésének biztosítása, az olasz tudományos és müvészeti élettel való kapcsolatteremtés volt.

1929 és 1942 között a Történeti Intézetben hatvannégy tudományos kutató, a Collegium Hungaricumban hetvennyolc olasz nyelv és irodalom tanár, zeneés művészettörténész, énekes, zenemüvész és író élt és kutatott legalább egy fél évig a római könyvtárakban és levéltárakban (Sárközy, 2010, 115-137.). Mellettük pedig a kétemeletes Mủvészházban szintén több mint száz festő és szobrász élt és dolgozott (Aba Novák Vilmos, Molnár C. Pál, Szőnyi István, Pátzay Pál, Vilt Tibor és társaik) néha éveken át, és képviselte a 20. század első felének egyik jellegzetes, „római iskolának” nevezett irányzatát (P. Szücs, 1987).

A tudományos ösztöndíjasok munkáit az Akadémia 1936 és 1942 között rendszeresen megjelentette az Akadémia Koltay Kastner Jenő, majd Genthon István szerkesztette évkönyveiben (Sárközy-Tolomeo, 1993, 117-134.). Az Akadémia kiállításokat rendezett az ott élő művészek müveinek bemutatására, és segített abban, hogy rendszeresen részt vegyenek az olaszországi nagy nemzetközi kiállításokon és a Velencei Biennálén (Borsányi, 2009, 141-153.).

1943 nyarán a Rómára is kiterjedő bombázások és az egyetemi oktatás felfüggesztése után a magyar kultuszminisztérium ideiglenesen beszüntette a Római Magyar Akadémia müködését. Genthon István igazgató és Tóth László akadémiai titkár és egyetemi magyar lektor hazatértek Magyarországra, míg az épületet a Pápai Intézetre bízták. Az akadémia a háború után másfél évvel, 1947 januárjában nyílt meg újra Kardos Tibor pécsi egyetemi magántanár, a magyar humanizmus kutatójának vezetésével. Segítőtársai Pásztor Lajos történész és Tóth László olasz 
nyelv és irodalom tanár voltak. Kardos Tibor a magyar kommunista párt megbízottjaként kapta meg kinevezését, de 1947-48-ban mindent megtett, hogy az akadémia a magyar kultúra és tudomány szolgálatában álljon, és lehetővé tette, hogy a háború borzalmai után a magyar irodalom, mủvészet és tudományos élet nagyjai és fiatal tehetségei Rómában tölthessenek egy-két hónapot. Ezekben az években neves tudósok és fiatal kutatók (Alföldi András, Balázs Béla, Fülep Lajos, Kerényi Károly, Lukács György, Szabolcsi Bence, illetve Hanák Péter, Herczeg Gyula, Jászay Magda, Klaniczay Tibor, Szauder József, Vayer Lajos és még sokan mások), művészek (Katona Jenő, László Margit, Szervánszky Péter, Takács Jenő, Zathureczky Ede; Ferenczy Béni, Hajnal János, Hantai Simon, Vilt Tibor és társaik) ismét a Palazzo Falconieriben lakhattak, és előadásokat, koncerteket tartottak az olasz közönség számára, műveiket az akadémia újonnan alapított tudományos folyóiratában a Janus Pannoniusban publikálták. Kardos Tibor egyik legnagyobb érdeme, hogy a háború szörnyüségei után a magyar irodalom egy egész generációja számára biztosította, hogy néhány hónapig Rómában élhettek. Érdemes felsorolni a neveket: Balázs Béla, Berczely Anzelm Károly, Csorba Győző, Déry Tibor, Lengyel Balázs, Nemes Nagy Ágnes, Károlyi Amy, Ottlik Géza, Pilinszky János, Takács Gyula, Toldalagi Pál, Thurzó Gábor, Vas István, Weöres Sándor, és néhány napra Rómában jártak előadást tartani és neves olasz írókkal találkozni Illyés Gyula és Cs. Szabó László is (Illyés, 1987; Lengyel, 1995; Csorba Gy., 2003; Hafner, 1977; illetve Vas István római versciklusa, a Római rablás [1962]).

A hazai politikai változások következtében és a hidegháború korának beköszöntével a Római Magyar Akadémia, mint az összes nyugati magyar intézet, beszüntette müködését. 1949 öszén abbamaradtak a külföldi ösztöndíjas utak, és bezárták az összes nyugati kulturális intézetet. Kardos Tibort és munkatársat hazarendelték (ezt a munkatársak közül többen megtagadták), és 1950-töl az intézet a római magyar követség kulturális „képviselete” lett, és a személyzet szállásaként vették igénybe.

Csak a hatvanas évek elején kezdődött el újra a Római Akadémián a tudományos és művészi ösztöndíjasok fogadása, melynek módozatait az 1965-ben kötött, máig érvényben lévő magyar-olasz kultúregyezmény szabályozta. Ekkor vette át „hivatalosan" a Magyar Tudományos Akadémiától az intézet irányítását és az ösztöndíjasok kiválasztását a Kulturális Kapcsolatok Intézete, majd a Mủvelődési Minisztérium Nemzetközi Kapcsolatok Főosztálya. Ez a hazai hivataloktól való függés a rendszerváltás után is fennmaradt (igaz, az új évezred elején a felügyeleti szerv a jelenleg a Külgazdasági és Külügyminisztérium alá tartozó Balassi Intézet lett).

A Római Magyar Akadémia hivatalos és tudományos irányításával 1959 elején Merényi Ferenc fiatal építészettörténészt bízták meg, akit hozzá hasonló pártfunkcionáriusok követtek (Benedetti Tibor 1965-1969; Kalmár György 19691973; Kis Aladár 1973-1977; majd ismét Merényi Ferenc 1977-1983 és Dósai István 1983-1990) (Csorba L., 1998, 59-62.). 
1975-78 között került sor az épület első nagy átépítésére, ekkor alakítottak ki a palota két felső emeletén az akadémiai és a nagykövetségi dolgozók családjai részére több szobás lakásokat, az első emeleten pedig elegáns hivatali szobákat. A Fraknói Vilmos által létesített könyvtár maradékát levitték a földszinti raktárakba, és a könyvtár helyén előadótermet alakítottak ki kulturális rendezvények céljára, míg az ösztöndíjasok és az ,átutazó vendégek” fogadására a kis kétemeletes egykori Mủvészház müteremlakásaiból alakítottak ki (tudományos és mủvészi alkotó munkára egyaránt alkalmatlan) kétágyas szobákat. Ahogy az 1960-ban ismét ösztöndíjas úton Rómában tartózkodó költő, Csorba Győző említi Római visszaemlékezésében: „a magyar követség, a konzulátus, a tájékoztató hivatal és mindenféle hivatal elfoglalta a nagy épületet, [...] a magunkfajta emberek (az ösztöndíjasok) csak hátul, a kispalotában kaptunk helyet. ...az akadémia ekkor már inkább fegyintézethez hasonlított" (Csorba Gy., 2003, 107-108.).

A hetvenes-nyolcvanas években a Római Magyar Akadémia egy vendégházzal is rendelkező kulturális hivatallá vált, mely azóta is jelentős hazai kiküldött apparátussal intézi a hazai intézmények olaszországi kulturális ügyeit, programjait és a palotában havonta különféle rendezvényeket tart (előadásokat, könyvbemutatókat, koncerteket, táncházat stb.) otthonról kiutaztatott előadókkal, müvészekkel, táncegyüttesekkel a római lakosok és az Örök Városban élő magyarok (föleg a kiküldött alkalmazottak családtagjai) számára.

Mindennek ellenére a Római Magyar Akadémia 1960-tól kezdve az ösztöndíjasok befogadásával komoly szerepet töltött be sok száz, sőt valószínűleg ezernél is több magyar müvész és kutató életében. Igaz, nem volt (és máig nincs) önálló kutatáshoz, müvészi alkotó tevékenységhez alkalmas elhelyezésük, nem áll többé rendelkezésükre a tudományos kutatáshoz szükséges, tudatosan fejlesztett szakkönyvtár ${ }^{2}$, megszüntették a festő- és szobrászműtermeket, 1949 óta nem biztosítanak az ösztöndíjasok számára étkezést, és az ösztöndíjak kicsisége megakadályozza, hogy rendes életet éljenek, de mindennek ellenére a hatvanas évektől kezdve több száz tanár, kutató és müvész több hónapig Rómában élhetett és dolgozhatott. Ahogy Szerb Antal írta még 1936-ban a fasiszta Olaszországban tett útja után: „Hogy jól vagy rosszul, boldogtalanul vagy boldogan, oly elenyésző ahhoz képest, hogy ott vagyok jól vagy rosszul, boldog, vagy boldogtalan" (Szerb, 1971, 628.).

A rendszerváltás első éveiben, majd a kilencvenes évek végén több kísérlet történt a Római Magyar Akadémia eredeti akadémiai funkciójának visszaállítására.

${ }^{2}$ A Fraknói Vilmos által létrehozott kiváló történeti könyvtár értékesebb részét még Tolnai Gábor nagykövet 1950-ben hazahozatta, és egy része az MTA könyvtárába került, igen sok kötet az 1975-78 közötti épületátalakítás alatti beázások és az ezt követő leselejtezés áldozatává vált. A háború óta a könyvtárnak nincs tervszerü gyarapítása, a kilencvenes évek közepén megszűnt a fontosabb szaklapok előfizetése, sosem volt és ma sincs önálló szakkönyvtárosa. Jelenleg semmiképp sem tekinthető tudományos könyvtárnak. 
Szörényi László nagykövetsége alatt ugyan elkezdődött a követségi hivatalok és lakások kiköltöztetése a fóépületből, egyre több tudományos konferenciát rendeztek, újralétesítették és 1996-2010 között megjelentették az akadémia évkönyveit (Pál, 2004, 221-226.), de a hírlapokban és folyóiratokban közölt cikkek, a Római Magyar Akadémiáról szóló kötetek, minisztériumi beadványok (Sárközy, 2015, 93-143.) ellenére máig nem sikerült visszaállítani az intézetnek azt a funkcióját, melyért 1895-ben, illetve 1928-ban létrehozták, nem sikerült elérni, hogy a Római Magyar Akadémia ismét tudományos intézet, akadémia legyen, mely mellett müvészház áll az ösztöndíjas művészek részére.

A Rómában a 19. század végén, a 20. század elején létesített külföldi tudományos és művészeti intézetek szinte mind megőrizték akadémiai jellegüket. Ezekben az intézetekben máig az igazgató és egy-két munkatársán kívül csak ösztöndíjas kutatók és müvészek laknak tudományos, illetve müvészi alkotótevékenységhez szükséges feltételek (szakkönyvtár, felszerelt műtermek stb.) mellett hosszabb időn keresztül, és az intézetek biztosítják az ott készített kutatások eredményeinek kiadását, az ott dolgozó mủvészek alkotásainak bemutatását és az olasz tudományos és müvészi élettel való folyamatos kapcsolatteremtést.

Ezzel szemben a Római Magyar Akadémia immár fél évszázada „vegyes intézetként" müködik. Az egyre kisebb számú ösztöndíjas és az egyre nagyobb számú átutazó „,programvendéget” a múvészházban helyezik el, míg a Falconieri palotában (a II. emeleti Pápai Intézet kivételével) ma csak „hivatalok” és személyzeti lakások vannak. A Római Magyar Akadémia irányítását és szakmai felügyeletét 2002 óta a Balassi Intézet biztosítja és nevezi ki az intézet vezetőit, 2007-óta dönt az (egyre kevesebb) ösztöndíjas, valamint a hazulról az intézet által kiválasztott előadók, előadóművészek és együttesek kiválasztásáról és kiküldetéséről.

2016-ban a Balassi Intézet a Külgazdasági és Külügyminisztérium alá lett rendelve, így még erősebben érezhető a Római Magyar Akadémia tudományos jellegének háttérbe szorulása, hiszen az intézetben lakó és dolgozó munkatársak munkája elsősorban a Nagykövetségtől és a Balassi Intézettől otthonról kapott megbízatások olaszországi intézéséből, a hazulról kiküldött művészek, együttesek rendezvényeinek megszervezéséből, kulturális ismeretterjesztéséböl áll, és csak nagyon kis mértékben tudományos kutatások és müvészeti alkotómunka segítéséből. Félő, hogy amennyiben ez a gyakorlat a Nagykövetség átépítését követően, a követségi hivatalok eredeti helyükre visszaköltözése után is tart, az is bekövetkezhet, hogy az intézetet ki fogják zárni a római külföldi tudományos intézetek szövetségéből. ${ }^{3}$

${ }^{3} \mathrm{Az}$ Unione Internazionale degli istituti di archeologia, storia e di storia dell'arte in Roma szervezetben a következő országokhoz tartozó külföldi intézetek vesznek részt: Ausztria, Belgium, Cseh Köztársaság, Dánia, Finnország, Franciaország, Hollandia, Lengyelország, Magyarország, Nagy-Britannia, Németország, Norvégia, Románia, Spanyolország, Svájc, Svédország, Vatikán. 
Éppen ezért nagy szükség lenne arra, hogy a Római Magyar Akadémián és a még meglévő nagy hagyományú nyugati Collegium Hungaricumokban a tudományos kutatások felügyelete és az ösztöndíjas kutatók kiválasztása ismét a Magyar Tudományos Akadémia erre alapítandó kuratóriuma alá kerülhessen, ugyanakkor a Rómában hosszabb ideig alkotni és műveiket kiállítani kívánó művészek kiválasztása a Magyar Múvészeti Akadémia feladata lehetne. Az ösztöndíjakat odaítélő bizottságokban természetesen részt vennének a Balassi Intézetbe olvasztott Ösztöndíj Bizottság képviselői is. A Külgazdasági és Külügyminisztérium alá tartozó Balassi Intézet pedig továbbra is ellátná a Római Magyar Akadémián és más olasz, illetve külföldi városokban a kulturális rendezvények szervezését.

Az Akadémia igazgatójának nemzetközileg elismert egyetemi tanárnak, tudósnak vagy művésznek kell lennie, akit az MTA és az MMA kuratóriuma választana ki, akinek fö feladata a tudományos kutatók és a múvészeti ösztöndíjasok római munkájának segítése, olaszországi kapcsolatainak biztosítása, az olasz tudományos életben való aktív részvétel lenne.

Ezzel egy időben vissza kell állítani a fóépületben a tudományos kutatók lakásait és a melléképületben a mütermekkel ellátott ösztöndíjas lakásokat. Ebben a nagy négyemeletes palotában igazán megférnének egymás mellett az akadémiai munkatársak, az esetleg itt elhelyezendő követségi alkalmazottak, valamint a tudományos (akadémiai) ösztöndíjas kutatók lakásai. A palota melletti kétemeletes egykori Mủvészház Tevere-partra néző nagy üvegablakos szobáiban ismét a müvészek részére lehetne kialakítani müteremlakásokat, a másik, Via Giuliára néző felében pedig a „péhádés” ösztöndíjasok és „programvendégek” számára lehetne biztosítani elhelyezést. Így a Balassi Intézet által szervezett kulturális rendezvények további megtartása mellett vissza lehetne állítani a Római Magyar Akadémia tudományos (akadémiai) jellegét és a nagy hagyományú római magyar mủvészházat, és megelőzhető lenne, hogy tudományos és mủvészi alkotó tevékenység és ösztöndíjasok hiánya miatt a hivatalok, követségi és akadémiai alkalmazottak lakásai által elfoglalt, a Balassi Intézet által működtetett Római Magyar Akadémiát megfosszák az „akadémia” név használatától, és kizárják a római külföldi tudományos intézetek köréből (mint történt 1950-1995 között).

Remélhetőleg jövőre, 2019-ben, az első római akadémiai év kilencvenedik évfordulójára a Római Magyar Akadémia ismét tudományos intézménnyé válhat, ahol az MTA által kiválasztott tudományos kutatóknak, doktoranduszoknak és az MMA által kiutaztatott müvészeknek éppúgy lesz hely, mint a kulturális rendezvényeket biztosító hivatali munkatársak számára. 


\section{IRODALOM}

Borsányi K. (2009): L'arte ungherese nella stampa italiana alla Biennale di Venezia. Rivista di Studi Ungheresi, La Sapienza, Roma, XXIII, 8, 141-153.

Csorba Gy. (2003): Római följegyzések 1947-48. Pécs: Pro Pannonia Kiadói Alapítvány

Csorba L. (szerk.) (1998): Száz év a magyar-olasz kapcsolatok szolgálatában. Magyar tudományos, kulturális és egyházi intézetek Rómában 1895-1995. Budapest: HG\&Társa (olasz nyelven is)

Csorba L. (1998): A Római Magyar Akadémia története 1945 után. In: Száz év a magyar-olasz kapcsolatok szolgálatában. Budapest: HG\&Társa, 59-62.

Fráter J. (1974): A Római Magyar Történeti Intézet bizottsága. In: MTA állandó bizottságai 18541949, Budapest: MTA, 1974, 251-262.

Genthon I. (1973): Római napló. Budapest: Corvina

Hafner Z. (szerk.) (1977): Pilinszky Rómában, 1947, 1967. Budapest: Kortárs Kiadó

Illyés Gy. (1987): Naplójegyzetek, 1947. Kortárs, 3.

Lengyel B. (1995): Két Róma. Budapest: Balassi Kiadó

Molnár A. -Tamás T. (2016): Palazzo Falconieri. Róma-Budapest, Balassi Intézet (olasz nyelven is)

Pál J. (2004): A „Fraknói” Történeti Intézet létrejötte a Római Magyar Akadémián (1996-1998). Magyar Tudomány, 2, 221-226. http://www.matud.iif.hu/04feb/010.html

Pásztor L. (1993): Le origini dell'Accademia d’Ungheria di Roma. In: Sárközy P. - Tolomeo, R. (a cura di): Un istituto scientifico a Roma: l'Accademia d'Ungheria di Roma. Roma: Periferia

P. Szűcs J. (1987): A 'Római iskola'. Budapest: Corvina Kiadó

Sárközy P. (2010): A Római Magyar Akadémia tudományos tevékenysége 1929-2009. In: Sárközy P.: Róma mindannyiunk közös hazája. Róma magyar emlékei - magyarok emlékei Rómáról. Budapest: Romanika, 115-137.

Sárközy P. (2010): Róma mindannyiunk közös hazája. Róma magyar emlékei-magyarok emlékei Rómáról. Budapest: Romanika

Sárközy P. (2015): 'Andata e ritorno', Római jegyzetek, 1990-2015. Budapest: Nap Kiadó

Sárközy P. - Tolomeo R. (a cura di) (1993): Un istituto scientifico a Roma, L'Accademia d'Ungheria 1895-1950. Cosenza: Periferia

Szerb A. (1971): A harmadik torony. In: Szerb A.: Gondolatok a könyvtárban. Budapest: Magvető Kiadó

Tóth T. (2017): Pápai Magyar Intézet, Róma. Róma-Budapest: PIM

Ujváry G. (1998): A Római Magyar Intézet története 1912-1942 között. In: Csorba L. (szerk.) (1998): Száz év a magyar-olasz kapcsolatok szolgálatában. Magyar tudományos, kulturális és egyházi intézetek Rómában 1895-1995. Budapest: HG\&Társa, 20-24.

Vári R. (1916): Történeti Intézetek Rómában. Budapest: MTA

Vas I. (1962): Római rablás. Budapest, Magvető Kiadó 